\title{
STUDENTS' SPEAKING ANXIETY IN AN EFL CLASSROOM: GENDER PERSPECTIVE AT SMA NEGERI 2 KENDARI
}

\author{
Kiki Purwanti \\ Amir Jaya \\ Muh. Khusnun Muhsin \\ English Department \\ Halu Oleo University
}

Email: purwanti.kiki@yahoo.com

\begin{abstract}
The aim of this study was to find out whether or not there was a significant difference of students' speaking anxiety across gender. This study used survey method. The population was the second grade students of SMAN 2 Kendari in academic years 2017/2018. This study involved 184 students (92 males and 92 females) who were taken from proportionated stratified by random sampling. An instrument employed in this study was a questionnaire of Foreign Language Classroom Anxiety Scale (FLCAS). The data were analyzed by using descriptive and inferential statistic. The result of descriptive analysis showed that students' speaking anxiety was affected by three factors namely communication apprehension, test anxiety, and fear of negative evaluation where each factor had a neutral position and majority students had a moderately anxious level on speaking anxiety. The result of the t-test showed that $t_{\text {observed }}$ was -2.007 and $t_{\text {table }}$ was 1.973 . It means that $t_{\text {table }}$ was

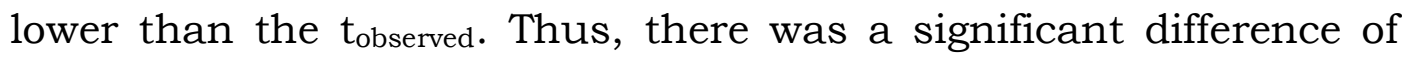
speaking anxiety between male and female students where females were more anxious then male.
\end{abstract}

Keywords: Speaking Anxiety, situation-specific Anxiety, and Gender.

\section{Introduction}

Students' lack of speaking still becomes a national problem in Indonesia. It can be looked at the fact that although the students have been learning English from elementary, junior, and senior high school, they do not have a good speaking skill. Teachers have been trying to use various methods to improve the students' 
speaking skill but students still have difficulties in speaking. The students' sometimes know and understand the teacher's questions but they tend to be silent. The students do not feel comfortable to speak in front of others (Cheng, 2009).

The phenomenon above happened because of many factors. Anxiety is one of the factors that cause the students could not develop their speaking skill. According to Post (1978), anxiety is an unpleasant emotional condition, which is characterized by active central nervous system. This is also supported by Freud (1978) who states that anxiety is unpleasant feeling which is followed by certain psychological reaction that changes heart rate and breathing. As part of the learners' affective filter, anxiety might interfere with the process of learning another language. Similarly, Liu (2006) said that anxiety can negatively affect learners' achievement in the target language particularly in speaking foreign language.

The focus of this study is on anxiety and gender differences. Many studies (Mahmoodzadeh, 2012; Gürbüz \& Öztürk, 2012; Mesri, 2012; Week \& Ferraro, 2011) have been conducted to investigate gender factor in foreign language learning. Gender has an important role in foreign language classes. Female students are generally found to be anxious. Yet, they are found to be more motivated and successful than male students in foreign language classes (Park \& French, 2013; Öztürk \& Gürbüz, 2012; Mesri, 2012).

Anxiety is an important factor which affects language learning, particularly speaking skill. Different learners both male and females have different levels of anxiety and it may delay their second language speaking. The study of Week \& Ferraro (2011) 
also does not support the hypothesis that males have a more negative view and lower aptitude towards language than females.

Some researchers investigated speaking anxiety in English Foreign Language Classroom (EFLC). Liu (2006) found that the students even became more anxious when they were given questions or asked to perform in front of the class. Similarly, Horwitz, Horwitz, \& Cope (1986) found that students were afraid of speaking in foreign language class because they were afraid of making mistakes and though as less competent by others. Mahmoodzadeh (2012) has investigated foreign language anxiety within the EFL Learner's interlanguage system at Iranian learners with the total sample was 74 students consisting of 31 Males and 43 females. The result of his study showed that female participants were more anxious than male in foreign language speaking anxiety.

The condition above also happened at SMA Negeri 2 Kendari. It was based on the result of the interview with some students. They said that they were nerveous, shy, panic, self confidence, lack of vocabulary, worries if the teacher asked question. They were also fear when they were required to demonstrate their ability to speak English in front of class. The reseacher concluded that the underlying reason behind this phenomenon is anxiety.

Regarding the issue, this study was conducted to answer the following question: "Is there any significant difference of students' speaking anxiety between male and female students of SMA Negeri 2 Kendari?”

\section{Literature Review}

The Concept of Anxiety

Everyone feels anxious at some time or another. Fear and worries are common in children, teenagers and even for adults. This is a normal part of development. According to Horwitz et al. 
(1986), MacIntyre and Gardner (1991), Tang (2005) anxiety is the subjective sense of suspense, apprehension, nervousness, and worry related to appeal of the autonomic nervous system.

Mesri (2012: 148) stated that there are three types of perspectives from which research studies on anxiety are conducted. They are trait anxiety, state anxiety, and situationspecific anxiety. According to Scovel (1978), trait anxiety is an aspect of personality trait that is more permanent disposition to be anxious. It could be concluded that trait anxiety is a part of one's character and such students have a general predisposition to become anxious in various situations. Spielberger (1983) stated that state anxiety is thoughtfulness experienced at a particular moment or situation. It means that state anxiety is a nervous feeling at any situation that happens only particular moment. Finally, Ellis (1994) stated that situational anxiety is related to apprehension felt at specific situation and event. Unlike trait and state perspective, situation-specific perspective requires the respondents to ascribe their anxiety to particular sources.

According to Horwitz et al. (1986), there are three components of foreign language anxiety namely communication apprehension, test anxiety, and fear of negative evaluation. Communication apprehension refers to worry about oral communication (Horwitz et al., 1986). The basic cause of communication apprehension is some personality traits such as shyness, quietness or reticence. Test anxiety is an apprehension towards academic evaluation. Horwitz et al., (1986) stated that test anxiety refers to learners' negative expectations about their performance in an upcoming test. Fear of negative evaluation is observed when foreign language learners feel incapable of making the proper social impression and it is apprehension towards 
evaluations by others and avoidance of evaluative situations. Horwitz et al., (1991) stated fear of negative evaluation refers to individuals' worries about what others think about them and believe that those thoughts are usually negative.

Speaking Anxiety in a Psychological Context

Samuelsson (2011) cites the cognitive-behaviorist approach which views speaking anxiety as the most common form of social anxieties. He defines speaking anxiety as difficulty to speak in group. These difficulties are very in the cases of prepared speeches, oral presentations, answering questions or simple presentation. Samuelsson (2011) also claims that speaking anxiety is a specific social phobia that $15-20 \%$ of human population suffers, and it could be a hindrance in studies and life in general. This opinion infroms the reader that speaking anxiety is becaming human suffers and as a hindrance for reaping the students' success in speaking test.

Gender in Relation to Foreign Language Anxiety and Speaking Anxiety

Boyd and Bee (2006) concluded that there are some points in gender differences. First, they state that male show more physical aggression (such as hurts others physically or poses a threat of such damage) and more assertiveness than female do. Female simply expresses their aggressiveness in a different way using what has recently been labeled relational aggression (peer relationship by cruel gossip, ostracism, or facial expression of insult). This statement is also supported by Santrock (2008) as what he said that male is more physically aggressive than female who is more verbal aggression such as screaming. From the IQ scores side, male typically does better on tests of advanced mathemathical ability. Female does somewhat better on verbal tasks. (Boyd and 
Bee, 2006). Further, Boyd and Bee (2006), Kuebli, Butler \& Fivush (1995) state that even in infancy, female uses gestures and language to express emotion more often than male does. Similarly, McClure (2000) said that females are more responsive to others' facial expression. These differences often lead to the perception that female are more emotionally sensitive.

With regard to learning process, Kato \& McEwen (2003) in Willis (2011) explain briefly about how stress and emotions are affecting learning process. They state as follows: "Stress in the classroom or in other places, especially when associated with anxiety or fear, will release a chemical called TMT or Trimethyltin into the brain. TMT may interfere with the development of brain cells. When TMT is in the brain during stress for a moment, there will be disruption in the short-term memory and work efficiency. After a rather long experience stress, TMT is associated with a reduction in storage and recall of long-term memory, motivation, and creative problem solving. Although students who are experiencing stress seems to work "harder", but the quality of their work will decrease. It means that if anxiety comes to the students in learning process especially speaking skill, the quality of the students' learning will decrease as the result of being anxious.

From all these points above, it can be summarized that emotions, depression, stress, gender, anxiety and learning are related to each other.

Research Method

This research employed survey method. The population of this study was the second year students of SMA Negeri 2 Kendari in academic year $2017 / 2018$. There were 343 students in academic year $2017 / 2018$. There were eleven classes on the second year students of SMA Negeri 2 Kendari. In conducting this study the 
researcher selected the sample by using random sampling through lottery system based on Slovin formula. There were 184 students which consisted of 92 male and 92 female in order to all the students have the same opportunity.

A close-ended questionnaire was used to provide the statistical information about the general picture of students' speaking anxiety. One research instrument namely "Foreign Language Classroom Anxiety Scale" was used to obtain the data. The calculation was divided into three positions such as positive, neutral and negative. Strongly agree and agree were categorized as positive aspect, neutral as neutral and negative referred to disagree and strongly disagree.

There were 33 items of the questionnaire. Based on pilot study, there were 9 items which were invalid. Thus, the total number of item was 24 items. Those items reflected the components of anxiety, namely communication apprehension (9 items), test anxiety (6 items), and fear of negative evaluation (9 items). There were two statements in the questionnaire (positive and negative). Item number, $2,4,5,6,7,8,10,11,12,13,14,14$, $15,16,17,19,22,23$ were positive statements and item number 1 , $9,18,20$, and 24 were negative statements.

The data were quantitatively analyzed by using SPSS IBM by calculating the means of participants' responses. There were two statistical techniques used to analyze the data namely descriptive and inferential statistics analysis. Descriptive statistics was used to investigate the close-ended questionnaire which measured the students' speaking anxiety. Inferential statistics was carried to find out gender differences. This analysis was used to test the hypothesis and find out whether there was or not a significant difference on students' speaking anxiety across gender. For the 
inferential analysis, t-test was employed. Prior to this, a test of normality and homogeneity was done.

\section{Findings}

The findings are divided into the result of the close-ended questionnaire which measures the students' speaking anxiety and whether or not there is a significant difference of students' speaking anxiety between male and female

Students' Speaking Anxiety

Students Respond to CA, TA, FNE's Aspect on Likert Scale 1-5

\begin{tabular}{|l|l|l|l|}
\hline & $\begin{array}{c}\text { Ccommunication } \\
\text { apprehension }\end{array}$ & Test anxiety & $\begin{array}{c}\text { Fear of } \\
\text { negative } \\
\text { evaluation }\end{array}$ \\
\hline Total Score & 523,73 & 525,84 & 510,03 \\
\hline $\begin{array}{l}\text { Total } \\
\text { Average }\end{array}$ & 2,85 & 2,86 & 2,77 \\
\hline
\end{tabular}

Based on the table above, the mean score for communication apprehension was 2.85 , test anxiety was 2.86 , which was the highest mean score and fear of negative evaluation was 2.77 which was the lowest mean score.

Adopted from the classification provided by Balem (2009) the average score has their own criteria from 'slightly anxious', 'moderately anxious', and 'highly anxious'. For more detail, the distribution of students' average score of anxiety level can be seen in table below:

The Students' Speaking Anxiety Level

\begin{tabular}{|c|l|c|c|c|}
\hline No. & \multicolumn{1}{|c|}{ Category } & $\begin{array}{c}\text { Interval } \\
\text { Score }\end{array}$ & Frequency & $\begin{array}{c}\text { Percentage } \\
(\%)\end{array}$ \\
\hline 1. & $\begin{array}{l}\text { Slightly } \\
\text { Anxious }\end{array}$ & $1.00-2.49$ & 46 & $25 \%$ \\
\hline 2. & $\begin{array}{l}\text { Moderately } \\
\text { Anxious }\end{array}$ & $2.50-3.49$ & 123 & $66,8 \%$ \\
\hline
\end{tabular}




\begin{tabular}{|c|l|c|c|c|}
\hline 3. & $\begin{array}{l}\text { Highly } \\
\text { Anxious }\end{array}$ & $3.50-5.00$ & 15 & $8,2 \%$ \\
\hline \multicolumn{3}{|c|}{ Total } & 184 & $100 \%$ \\
\hline
\end{tabular}

The table above shows the distribution of students' score based on their speaking anxiety level. The result showed that there were 46 students (25\%) who were categorized as 'slightly anxious', 123 students $(66,8 \%)$ were categorized as 'moderately anxious' and 15 students $(8,2 \%)$ were categorized as 'highly anxious'. It means that majority of students in speaking class were categorized as 'moderately anxious' in speaking.

Gender Difference with Regard to Anxiety

The comparison of factors contributing to students' speaking anxiety between male and female students indicates that both male and female students considered communication apprehension as the major contributor of their speaking anxiety, followed by fear of negative evaluation, and test anxiety.

Classification of the Most Influential Factors Contributing To

FLCAS between Male and Female Students

\begin{tabular}{|c|c|c|c|}
\hline No & $\begin{array}{c}\text { 3 Categories of } \\
\text { FLCAS }\end{array}$ & Male & Female \\
\hline 1 & $\begin{array}{c}\text { Communication } \\
\text { Apprehension }\end{array}$ & $36 \%$ & $38 \%$ \\
\hline 2 & Test Anxiety & $24 \%$ & $26 \%$ \\
\hline 3 & $\begin{array}{c}\text { Fear of Negative } \\
\text { Eavaluation }\end{array}$ & $35 \%$ & $36 \%$ \\
\hline Total & & $100 \%$ & $100 \%$ \\
\hline Table above shows that the mean score for female
\end{tabular}

responding to communication apprehension aspect was $38 \%$, test anxiety was $26 \%$, and fear of negative evaluation was $36 \%$. Mean 
score of male responded to communication apprehension aspect was $36 \%$, test anxiety was $24 \%$, and fear of negative evaluation was $35 \%$. It means that communication apprehension was the main cause of students speaking anxiety, both for male and female, followed by negative evaluation and test anxiety. The table also suggested that female students were more anxious than male in all aspects.

The result of the analysis showed that $\mathrm{T}_{\text {observed }}$ of the foreign language anxiety scale was -2.007 and df was 182 . To see whether $\mathrm{H}_{0}$ was accepted or rejected, the $\mathrm{T}_{\text {observed }}$ was consulted to the $\mathrm{T}_{\text {table }}$ at the .05 significance level. The result showed that the $t_{\text {table }}$ was 1.973. It means that $\mathrm{T}_{\text {table }}$ was lower than the $\mathrm{T}_{\text {observed. }}$ Hence, $\mathrm{H}_{0}$ was rejected and $\mathrm{H}_{1}$ was accepted. Based on the result, $\mathrm{T}_{\text {table }}$ was lower than $\mathrm{F}_{\text {observed }}$ and $p$ was .46. So, it can be concluded that there was a significant difference of students' anxiety between male and female students.

Discussion

Based on the findings, it was found students in speaking class experienced anxious feeling on three factors of language anxiety but in different degrees. Besides, majority of the students had a moderate anxious level on speaking anxiety.

The inferential analysis revealed that there was a significant difference of students' anxiety between males and females. The main point related to anxiety of these gender differences is the conclusion that females were more emotionally sensitive than male. Even in infancy, females use gestures and languages to express emotions more often than boys do (Kuebli, Butler \& Fivush (1995) in Boyd and Bee (2006). It is confirmed by Santrock (2008) that females were more likely to discuss emotions in terms of relationships and they were more likely to express fear and 
sadness. However, the present study provides evidence that the difference of students' speaking anxiety between male and female was significant. This raises a question because it is congruent with existing theories. The result claims that females were more anxious than males. This is supported by Mahmoodzadeh (2012) who has investigated foreign language anxiety within EFL Learner's interlanguage system at Iranian learners. The result of his study showed that female participant tended to be more disposed than male to experiencing foreign language speaking anxiety.

\section{Conclusion}

Based on the limited data, it could be concluded that there was a significant difference of students' speaking anxiety between males and females. Both male and female students experienced high anxiety on communication apprehension aspect followed by fear of negative evaluation and test anxiety. It is also found that female students were more anxious than male students.

\section{References}

Balem, S. H. (2009) The Sources of Foreign Language Speaking Anxiety and Their Relationship between Proficiency Level and Degree of Foreign Language Speaking Anxiety. Unpublished doctoral dissertation. Bilkent University. Ankara

Boyd, Denise Robert and Helen Bee. (2006). International Edition: Lifespan Development: Fourth Edition. Boston: Pearson Education, Inc.

Ellis, R. (1994). The study of second language acquisition.Oxford: Oxford University Press.

Freud, S. (1978). Psikoanalisis: A General Introduction to Psychoanalysis: Jogjakarta

Horwitz, E., K., Horwitz, M. B., \& Cope, J., A. (1986). Foreign language classroom anxiety.Modern Language Journal, 70, 125-32. 
Liu, M. (2006). Anxiety in Chinese EFL students at different proficiency levels. System, 34(3), 301-316.

MacIntyre, P. D. \& R. C. Gardner. (1991). Methods and results in the study of anxiety and language learning: A review of the literature. Language Learning, 41, 85-117.

Mahmoodzadeh, M. (2012). Investigating foreign language speaking anxiety within the EFL learner's interlanguage system: The case of Iranian learners. Journal of Language Teaching and Research, 3(3), 466-476.

Mesri, F. (2012). The Relationship between Gender and Iranian EFL Learners' Foreign Language Classroom Anxiety (FLCA). International Journal of Academic Research in Business and Social Sciences, 2(6).

Öztürk, G. \& Gürbüz, N. (2012). The impact of gender on foreign language speaking anxiety and motivation. Procedia - Social and Behavioral Sciences, 70 (2013) $654-665$.

Park, G. P., \& French, B. F. (2013). Gender differences in the Foreign Language Classroom Anxiety Scale. System, 41(2), 462-471.

Post, A. L. (1978). Self-disclosure as a function of state and trait anxiety. Journal of Consulting and Clinical Psychology, 46(1), 12-19.

Samuelson. (2011). Anxiety and cognitive processing of instruction. In R. Schwarzer (Ed.), Self related cognition in anxiety and motivation (pp. 35-54). Hillsdale, NJ: Erlbaum

Spielberger, C. D. (1966). Anxiety and behavior. Academic Press.

Tang, M. (2005). Survey and study of non-English major undergraduates' English learning anxiety in class. Taituan Normal University Journal (social science edition), 4: 145-146.

Week, M., \& Ferraro, R. (2011). Correlation between foreign language anxiety and gender. Psychology Journal, 8(1): 40-4.

Willis, J.M.D. (2011). Translate of Research Based Strategies to Ignite Student Learning. Mitra Media: Yogyakarta 